\title{
Rational Design of Transglutaminase Substrate Peptides for Rapid Enzymatic Formation of Hydrogels
}

\author{
Bi-Huang Hu and Phillip B. Messersmith* \\ Northwestern University \\ Biomedical Engineering Department \\ 2145 Sheridan Road \\ Evanston, IL 60208
}

\section{Experimental Section.}

\begin{abstract}
Materials.
4-armed PEG with amine end groups $\left(\overline{\mathrm{M}}_{\mathrm{w}}=10 \mathrm{k}\right)$ was purchased from SunBio PEG Shop. Hydroxyl terminated PEG $\left(\overline{\mathrm{M}}_{\mathrm{w}}=4 \mathrm{k}\right)$ and Sephadex ${ }^{\circledR}$ LH-20 were purchased from Fluka. Rink amide resin $(0.6 \mathrm{mmol} / \mathrm{g}), \mathrm{H}-\mathrm{Gly}-2-\mathrm{ClTrt}$ resin $(0.6 \mathrm{mmol} / \mathrm{g})$, DCC, BOP, HOBt, DIEA, NMP, and protected amino acids were purchased from Advanced ChemTech, KY, USA. Transglutaminase from guinea pig liver, Boc-LLys(Boc)-OH, and $N$-Boc-L-DOPA dicyclohexylammonium salt was purchased from Sigma Chemical Company (St. Louis, MO). Acetonitrile was from Burdick and Jackson. TFA was from J. T. Baker. Triethylamine $\left(\mathrm{Et}_{3} \mathrm{~N}\right)$, piperidine and water (HPLC grade) monodansyl cadaverine were purchased from Aldrich Chemical Company (Milwaukee, WI). Dansyl- $\varepsilon$-aminocaproyl-Gln-Gln-Ile-Val (dns- $\varepsilon$-aca-QQIV) was a gift from Dr. Laszlo Lorand of Northwestern University Medical School.
\end{abstract}

\section{Peptide Design.}

The Lys and Gln substrate peptides investigated in this study possessed basic design features reflecting known properties of biological macromolecules and synthetic peptide substrates of TGase. For the Gln substrate peptide, the use of a single Gln residue was immediately ruled out, as L-glutamines with either a free $\alpha$-amino group or a free $\alpha$-carboxyl group do not act as TGase substrates ${ }^{1}$. A Leu residue was placed adjacent to the Gln near the C-terminus, because this has been shown to result in a significant increase in Gln specificity. ${ }^{2}$ Regarding the number of contiguous Gln residues, the literature is clear that peptides become better TGase substrates with increasing number of contiguous Gln residues ${ }^{3,4}$, and proteins containing two or more adjacent Gln residues are known to be good substrates ${ }^{5}$. Although peptides containing up to five contiguous Gln residues were synthesized, only data regarding three or fewer contiguous Gln residues were obtained, since longer Gln sequences resulted in poorly soluble peptides. Regarding the Lys substrate peptides, it has been shown that the composition and sequence of the amino acids adjacent to lysine residues in peptide and protein substrates can have an effect on the amine specificity ${ }^{6}{ }^{7}$. Based on the model peptide Ac-Gly ${ }_{3}{ }^{-}$ Lys-Gly ${ }_{3}$, a significant increase in specificity was observed when the neighboring Gly residue on the N-terminal side of the Lys was replaced by a Leu residue ${ }^{8}$. Since Leu is a hydrophobic residue, several of the peptides investigated in this study contained hydrophobic residues (Leu or Phe) in this position. The effect of DOPA incorporation, either immediately adjacent to Lys, or separated from Lys by a Leu/Phe, was also investigated. Finally, a Gly residue was added on the C-terminal side of the Lys residue to act as a spacer between the Lys peptide and the polymer in the peptide-PEG conjugates, so that the peptide in the conjugate may be more accessible to TGase.

\section{Peptide Synthesis.}

C-terminal amidated peptides were synthesized manually on a Rink amide resin by the Fmoc solid phase peptide synthesis method. Reagents and solvents for peptide synthesis and protected Fmoc-amino acids were purchased from Advanced ChemTech. Boc-L-DOPA was used for the addition of N-terminal DOPA residue. ESI-MS analysis of peptides was performed on a LCQ LC-MS system (Finnigan, Thermoquest, CA). Results are shown in Table S1. Amino acid analysis of peptides was performed at the Protein Research Laboratory, University of Illinois at Chicago.

\section{Substrate Specificity.}

Enzymatic reactions were carried out in $50 \mathrm{mM}$ Tris- $\mathrm{HCl}$ buffer containing $5 \mathrm{mM} \mathrm{CaCl}, 5 \mathrm{mM}$ DTT, $1 \mathrm{mM}$ EDTA, $0.5 \mathrm{mM}$ dns- $\varepsilon$-aca-QQIV (or $1 \mathrm{mM}$ monodansyl cadaverine for glutamine peptides), varying amounts of a peptide substrate, and purified guinea pig liver transglutaminase (Sigma) (0.01-0.08 U/ml) in a total volume of $200 \mu \mathrm{l}$ of reaction mixture at $\mathrm{pH} 8.0,25^{\circ} \mathrm{C}$. At predetermined time intervals, aliquots of the reaction mixture were removed and added to an equal volume of $1 \%$ trifluoroacetic acid (TFA) in water or $1 \%$ TFA in water containing $0.2 \mathrm{mM}{ }^{\varepsilon} \mathrm{N}$ dansyl-L-lysine (Sigma) as the internal standard to terminate the reaction. All reaction products were characterized by LC-ESI/MS (Table S2) and quantitatively analyzed by RP-HPLC. Representative results for a few select peptides are shown in Figure S1-S4. Kinetic constants (Table S3 and Figure S5) were calculated from two methods: fit of the initial rates versus substrate concentrations to the Michaelis-Menten equation using the SigmaPlot $^{\boxplus} 2000$ program with Enzyme Kinetics Module (SPSS Inc., IL); and graphing of the kinetic data using the direct linear plot. A molecular weight of 90,000 Da was used to calculate the enzyme concentration ${ }^{9}$.

Peptide Selection and Protected Peptide Fragment Synthesis.

Under the assumption that poor peptide substrates would result in slow or no hydrogel formation when coupled to PEG, only selected substrates with good specificities were selected for coupling to PEG. Thus, among the Lys peptide substrates, DOPA-FKG was chosen for its high specificity and incorporation of DOPA residue. As for the Gln peptide, we chose Ac-GQQQLG- $\mathrm{NH}_{2}$ based on its good substrate properties and ease of synthesis. The peptides were synthesized manually as protected peptide fragments by Fmoc strategy on a H-glycine-2-chlorotrityl resin with the following amino acid side-chain protections: trityl (Gln), Boc (Lys), and Boc $\left(\alpha-\mathrm{NH}_{2}\right.$ of DOPA). Protected peptide fragments were obtained by treatment of the resin with $1 \%$ TFA in dichloromethane (DCM), and the cleaved peptide sequences were confirmed by MALDI TOF-MS analysis. 


\section{Peptide-PEG Conjugate Design.}

Our original design incorporated both Lys and Gln peptides within one PEG molecule, as shown in peptide-PEG conjugate 3. However, crosslinking experiments of $\mathbf{3}$ with TGase demonstrated that the enzyme catalyzed primarily intermolecular crosslinking of Lys and Gln residues, and no gel formation was observed. To avoid intermolecular crosslinking, all subsequent experiments employed separate Lys and Gln functionalized PEGs, as represented by peptide-PEG conjugates $\mathbf{1}$ and $\mathbf{2}$ reported in the manuscript.

\section{PEG-Lysine Peptide Conjugate (1) Synthesis.}

The synthetic approach is shown in Scheme S1. $20 \mathrm{~g}(10 \mathrm{mmol}$ of $-\mathrm{OH})$ PEG diol in $50 \mathrm{ml}$ DCM and $100 \mathrm{ml}$ benzene was azeotropically concentrated under reduced pressure to dry the sample, and the residue was dissolved in $50 \mathrm{ml}$ of DCM. To PEG diol solution, $15 \mathrm{mmol}$ of Boc-

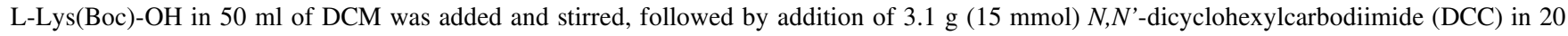
$\mathrm{ml}$ of DCM, and stirred at room temperature overnight. The solution was filtered to remove the solid and concentrated under reduced pressure to afford the product PEG-di-Boc-L-Lys(Boc). Proton NMR confirmed the existence of Boc group in the purified product. PEG-di-Boc-L-Lys(Boc) was then treated with $100 \mathrm{ml}$ of $4 \mathrm{M}$ hydrogen chloride in dioxane at room temperature for $2 \mathrm{hr}$, and concentrated under reduced pressure. Addition of ether to the residual solution precipitated the product. The product, PEG-di-K, was collected by filtration and dried in vacuum. MALDI TOF-MS confirmed the product structure, and ninhydrin test gave a dark blue color, indicating that the Boc protection group was removed.

A solution of $354 \mathrm{mg}(0.48 \mathrm{mmol})$ Boc-DOPA-Phe-Lys(Boc)-Gly-OH, $400 \mathrm{mg}$ (0.4 mmol) PEG 4000 di-K, $212 \mathrm{mg}$ (0.48 mmol) benzotriazole-1-yl-oxy-tris (dimethylamino) phosphonium hexafluorophosphate (BOP), $74 \mathrm{mg}(0.48 \mathrm{mmol}) \mathrm{N}$-hydroxybenzotriazole (HOBt) and $157 \mu 1(0.9 \mathrm{mmol}) \mathrm{N}, N^{\prime}$-diisopropylethylamine (DIEA) in $3 \mathrm{ml}$ of DCM was stirred for $2 \mathrm{hr}$ at room temperature, followed by addition of cold ether to precipitate the product. The product was collected through centrifugation, dried and treated with TFA-DCM (1:1) at room temperature for $60 \mathrm{~min}$. The solution was dried, and the residue was dissolved in $20 \mathrm{ml}$ of methanol, followed by addition of $20 \mathrm{ml}$ of ether. After storage at $-20^{\circ} \mathrm{C}$ overnight, the solid was collected by centrifugation and dried in vacuum. The product (1) was further purified by preparative RP-HPLC, and confirmed by MALDI TOF-MS analysis.

\section{PEG-Glutamine Peptide Conjugate (2) Synthesis.}

The synthetic approach is shown in Scheme S2. A solution of $0.66 \mathrm{~g}(0.48 \mathrm{mmol})$ Ac-Gly-Gln(Trt)-Gln(Trt)-Gln(Trt)-Leu-Gly-OH, $0.212 \mathrm{~g}(0.48$ $\mathrm{mmol}) \mathrm{BOP}, 74 \mathrm{mg}(0.48 \mathrm{mmol}) \mathrm{HOBt}$, and $250 \mu \mathrm{l}(1.44 \mathrm{mmol})$ DIEA in $4 \mathrm{ml}$ of DCM was stirred for 10 min at room temperature, followed by addition of $1 \mathrm{~g}\left(0.4 \mathrm{mmol}\right.$ of $\left.\mathrm{NH}_{2}{ }^{-}\right)$4-armed PEG amine, and stirred overnight. The solution was dried, and the residue was dissolved in $5 \mathrm{ml}$ of $\mathrm{MeOH}$. To the $\mathrm{MeOH}$ solution, $45 \mathrm{ml}$ of cold ether was added and stored at $-20^{\circ} \mathrm{C}$ overnight. The precipitate PEG4aQ(Trt) was collected through centrifugation, dried and further purified by passing through a Sephadex LH-20 column. PEG4aQ(Trt) was treated with TFA-triisopropylsilane (TIS)- $\mathrm{H}_{2} \mathrm{O}(92: 6: 2)$ at room temperature $2 \mathrm{hr}$. The solution was dried, and the residue was washed with cold ether (50 ml x 2), and dissolved in 50 $\mathrm{ml}$ of water. The insoluble solid was removed by centrifugation, and the solution was frozen and lyophilized. The lyophilized product (2) was further purified by preparative RP-HPLC, and confirmed by MALDI TOF-MS analysis.

\section{Hydrogel Formation.}

Three solutions were prepared as follows: Solution 1. $4 \mathrm{mM}$ PEG4aQ and $10 \mathrm{mM} \mathrm{CaCl}_{2}$ in $75 \mathrm{mM}$ Tris-HCl, pH 8.0, 1.33 mM EDTA; Solution 2. $8 \mathrm{mM}$ PEG4KK in water; and Solution 3. Transglutaminase from guinea pig liver (16 U/ml) in $50 \mathrm{mM}$ Tris-HCl, pH 8.0, $20 \mathrm{mM} \mathrm{DTT,} 1.33 \mathrm{mM}$ EDTA. All solutions were cooled on ice for $10 \mathrm{~min}$, after which $25 \mu \mathrm{l}$ of solution 2, $25 \mu \mathrm{l}$ of solution 3, and $50 \mu \mathrm{l}$ of solution 1 were mixed on ice. After being vortexed, the solution was incubated at $37^{\circ} \mathrm{C}$ for $10 \mathrm{~min}$. The final reaction solution consisted of $2 \mathrm{mM}$ PEG4aQ and $2 \mathrm{mM}$ PEG4KK in $50 \mathrm{mM}$ Tris- $\mathrm{HCl}, \mathrm{pH} 8.0\left(25^{\circ} \mathrm{C}\right), 5 \mathrm{mM} \mathrm{CaCl}_{2}, 5 \mathrm{mM}$ DTT, $1 \mathrm{mM}$ EDTA. Additional experiments utilizing a mixture of conjugate 2 and LysPEG-Lys (4 mM each) with TGase resulted in no hydrogel formation. The lack of reactivity of Lys-PEG-Lys was not unexpected, given the low specificity of single Lys residues as demonstrated in the literature ${ }^{1}$.

\section{Oscillatory Rheology.}

Oscillatory rheological experiments were performed with a Paar Physica MCR300 Rheometer with a Peltier device to control temperature using a stainless steel parallel plate $\left(25 \mathrm{~mm}\right.$ in diameter). Three solutions were prepared on ice as follows: Solution $1.8 \mathrm{mM} \mathrm{PEG4aQ} \mathrm{and} 20 \mathrm{mM}$ CaCl${ }_{2}$ in $200 \mathrm{mM}$ MOPS, pH 7.20; Solution 2. $16 \mathrm{mM}$ PEG4KK and $2 \mathrm{mM}$ EDTA in water; and Solution $3.20 \mathrm{mM}$ DTT and $2 \mathrm{mM}$ EDTA in water. $125 \mu \mathrm{l}$ each of solution 2 and solution 3, and $250 \mu \mathrm{l}$ of solution 1 were added into a vial containing $2 \mathrm{U}$ of tissue transglutaminase from guinea pig liver and mixed on ice. After vortexing, $400 \mu \mathrm{l}$ of the solution ( $4 \mathrm{mM}$ PEG4aQ and $4 \mathrm{mM}$ PEG4KK in $100 \mathrm{mM} \mathrm{MOPS}, \mathrm{pH} 7.2,10 \mathrm{mM} \mathrm{CaCl}_{2}, 5$ mM DTT, $1 \mathrm{mM}$ EDTA, and $4 \mathrm{U} / \mathrm{ml}$ tissue transglutaminase) was loaded onto the thermostated rheometer plate $\left(37^{\circ} \mathrm{C}\right)$, and the top parallel plate ( $25 \mathrm{~mm}$ in diameter) was positioned to hold the solution in a $0.8 \mathrm{~mm}$ gap between the two plates. After mineral oil was applied to the edge of the parallel plate for evaporation control, data were collected every $20 \mathrm{~s}$ over $60 \mathrm{~min}$. The measurements of the storage and loss modulus were taken at $37^{\circ} \mathrm{C}$ in the oscillatory mode at $1 \mathrm{~Hz}$ frequency and $1 \%$ strain during crosslinking (Figure S6a). After the gelation experiment, a frequency sweep experiment was performed from $0.001 \mathrm{~Hz}$ to $10 \mathrm{~Hz}$ with 12 data points at $1 \%$ strain (Figure S6b). Finally, a strain sweep experiment was performed with strain from $1 \%$ to $100 \%$ at $1 \mathrm{~Hz}$ frequency (Figure S6c).

\section{References.}

(1) Folk, J. E.; Cole, P. W. Journal of Biological Chemistry 1965, 240, 2951-2960

(2) Gross, M.; Whetzel, N. K.; Folk, J. E. Journal of Biological Chemistry 1975, 250, 4648-4655.

(3) Gorman, J. J.; Folk, J. E. Journal of Biological Chemistry 1980, 255, 419-427.

(4) Kahlem, P.; Terre, C.; Green, H.; Djian, P. Proceedings of the National Academy of Sciences of the United States of America 1996, 93, $14580-14585$.

(5) Hohenadl, C.; Mann, K.; Mayer, U.; Timpl, R.; Paulsson, R.; Aeschlimann, D. Journal of Biological Chemistry 1995, $270,23415-23420$.

(6) Groenen, P.; Smulders, R.; Peters, R. F. R.; Grootjans, J. J.; Vandenijssel, P.; Bloemendal, H.; Dejong, W. W. Eur. J. Biochem. 1994, 220, 795-799.

(7) Grootjans, J. J.; Groenen, P.; Dejong, W. W. Journal of Biological Chemistry 1995, 270, 22855-22858.

(8) Gross, M.; Whetzel, N. K.; Folk, J. E. Journal of Biological Chemistry 1977, 252, 3752-3759.

(9) Folk, J. E.; Cole, P. W. Journal of Biological Chemistry 1966, 241, 5518-5525. 
Table S1. Lysine-containing synthetic peptides studied.

\begin{tabular}{|c|c|c|c|c|}
\hline \multirow{2}{*}{ No. } & \multirow{2}{*}{ Sequence } & \multicolumn{2}{|c|}{$\mathrm{Mw}^{*}$} & \multirow{2}{*}{$\mathrm{Rt}^{\dagger}$} \\
\hline & & Calc & Detd & \\
\hline 1 & Ac-KG-NH & 244.2 & 244.1 & 4.02 \\
\hline 2 & FKG-NH & 349.2 & 349.2 & 13.75 \\
\hline 3 & LKG-NH ${ }_{2}^{2}$ & 315.2 & 315.2 & 7.87 \\
\hline 4 & Dopa-KG-NH & 381.2 & 381.2 & 5.60 \\
\hline 5 & Ac-FKG-NH & 391.2 & 391.2 & 19.73 \\
\hline 6 & Ac-LKG-NH & 357.2 & 357.2 & 17.72 \\
\hline 7 & Dopa-FKG-NH & 528.3 & 528.3 & 18.26 \\
\hline 8 & Dopa-LKG-NH & 494.3 & 494.3 & 16.06 \\
\hline
\end{tabular}

Table S2. Identification of enzymatic reaction products.

\begin{tabular}{ccccc}
\hline \multirow{2}{*}{ No. } & \multicolumn{2}{c}{ Sequence* $^{*} \mathrm{Mw}^{\dagger}$} & $\mathrm{Rt}^{\ddagger}$ \\
& & $\mathrm{Calc}$ & Detd & \\
1 & $\mathrm{Ac}-\mathrm{K}(\mathrm{Q}) \mathrm{G}-\mathrm{NH}_{2}$ & 1059.6 & 1059.3 & 22.34 \\
2 & $\mathrm{FK}(\mathrm{Q}) \mathrm{G}-\mathrm{NH}_{2}$ & 1164.6 & 1164.6 & 24.42 \\
3 & $\mathrm{LK}(\mathrm{Q}) \mathrm{G}-\mathrm{NH}_{2}$ & 1130.6 & 1130.5 & 23.28 \\
4 & $\mathrm{Dopa}-\mathrm{K}(\mathrm{Q}) \mathrm{G}-\mathrm{NH}_{2}$ & 1196.6 & $\mathrm{n} / \mathrm{d}$ & $\mathrm{n} / \mathrm{d}$ \\
5 & $\mathrm{AC}-\mathrm{FK}(\mathrm{Q}) \mathrm{G}-\mathrm{NH}_{2}$ & 1206.6 & 1206.4 & 27.50 \\
6 & $\mathrm{AC}-\mathrm{LK}(\mathrm{Q}) \mathrm{G}-\mathrm{NH}_{2}$ & 1172.6 & 1172.4 & 26.51 \\
7 & $\mathrm{Dopa}-\mathrm{FK}(\mathrm{Q}) \mathrm{G}-\mathrm{NH}_{2}$ & 1343.7 & 1343.4 & 25.14 \\
8 & $\mathrm{Dopa}-\mathrm{LK}(\mathrm{Q}) \mathrm{G}-\mathrm{NH}_{2}$ & 1309.7 & 1309.6 & 24.47 \\
\hline
\end{tabular}

*K(Q): $\varepsilon$-( $\gamma$-glutamyl dns-aca-QQIV) Lys; n/d: no product detected;

Calc: calculated monoisotopic molecular weight;

Detd: determined molecular weight by LC-ESI/MS; ${ }^{\ddagger}$ Rt: retention time in min.

Table S3. Kinetic constants of liver transglutaminase toward lysine peptides ${ }^{\dagger}$.

\begin{tabular}{|c|c|c|c|c|c|}
\hline No. & Sequence & $\begin{array}{l}\mathrm{K}_{\mathrm{m}, \text { app }} \\
(\mathrm{mM})\end{array}$ & $\begin{array}{c}\mathrm{V}_{\max , \text { app }} \\
(\mu \mathrm{M} / \min )\end{array}$ & $\begin{array}{r}\mathrm{k}_{\text {cat }} \\
\left(\min ^{-1}\right)\end{array}$ & $\begin{array}{c}\mathrm{k}_{\mathrm{cat}} / \mathrm{K}_{\mathrm{m}, \mathrm{app}} \\
\left(\min ^{-1} \mathrm{mM}^{-1}\right)\end{array}$ \\
\hline 1 & Ac-KG-NH ${ }_{2}^{*}$ & 0.872 & 1.02 & 9.2 & 10.6 \\
\hline 2 & $\mathrm{FKG} \mathrm{NH}_{2}^{2}$ & 0.498 & 1.70 & 30.6 & 61.6 \\
\hline 3 & LKG-NH & 0.609 & 1.64 & 29.5 & 48.4 \\
\hline 4 & Dopa-KG-NH & $\mathrm{n} / \mathrm{d}$ & $\mathrm{n} / \mathrm{d}$ & $\mathrm{n} / \mathrm{d}$ & --- \\
\hline 5 & Ac-FKG-NH & $46.9 \times 10^{-3}$ & 1.46 & 26.3 & 560 \\
\hline 6 & Ac-LKG-NH & $56.0 \times 10^{-3}$ & 1.50 & 27.0 & 482 \\
\hline 7 & Dopa-FKG-NH & $17.0 \times 10^{-3}$ & 1.25 & 22.5 & 1324 \\
\hline 8 & Dopa-LKG-NH & $19.5 \times 10^{-3}$ & 1.28 & 23.0 & 1179 \\
\hline
\end{tabular}

$\mathrm{n} / \mathrm{d}$ : no product detected. guinea pig liver transglutaminase $0.01 \mathrm{U} / \mathrm{ml}$ and

reaction time $3 \mathrm{~min}$. "enzyme $0.02 \mathrm{U} / \mathrm{ml}$ and reaction time $18 \mathrm{~min}$.

For DOPA-Lys-Gly- $\mathrm{NH}_{2}$ with concentration $0.05-50 \mathrm{mM}$, enzyme $0.05 \mathrm{U} / \mathrm{ml}$,

and reaction time $30 \mathrm{~min}$, no product was detected. 

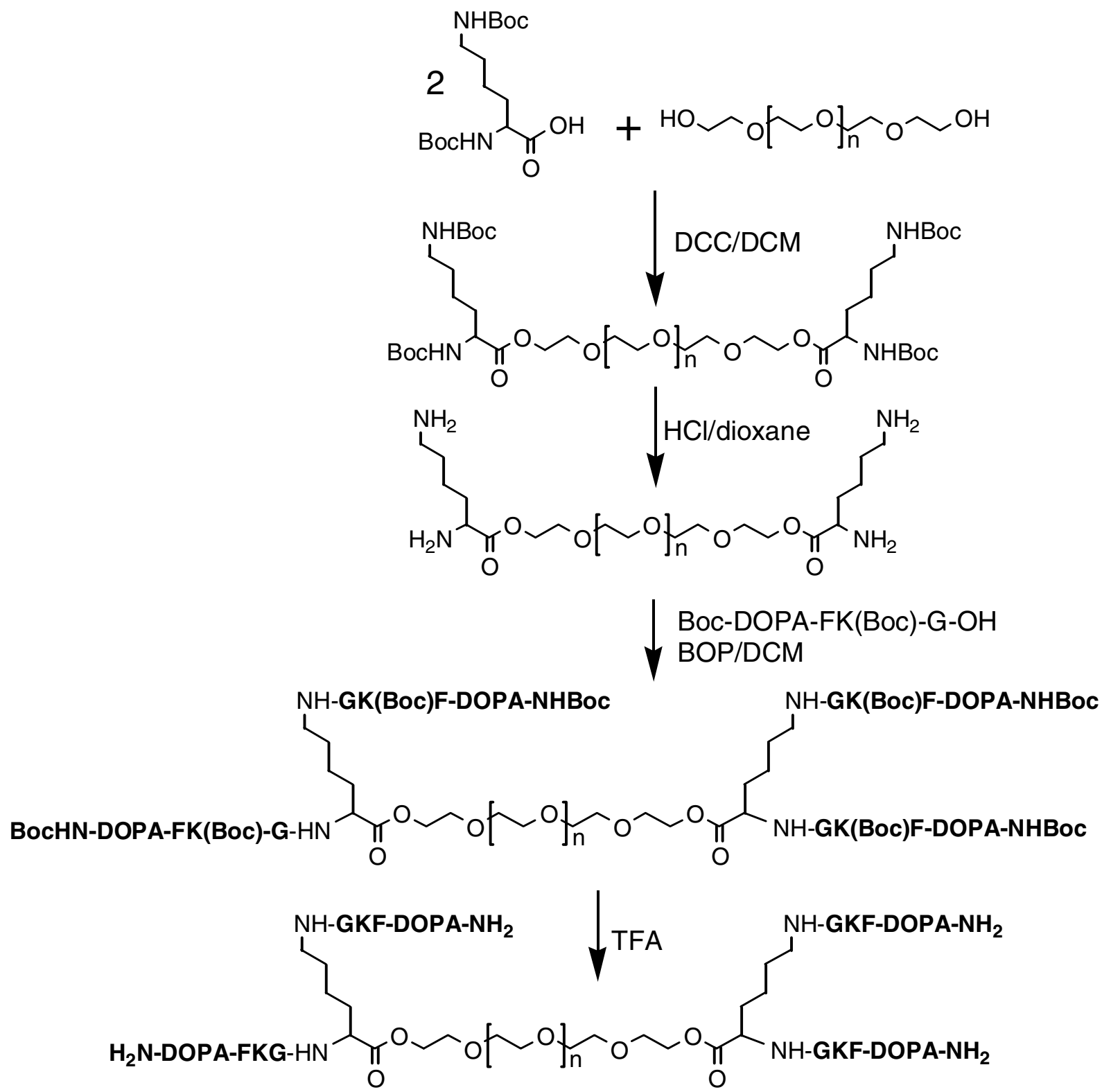

Scheme S1. Synthesis and structure of peptide-PEG conjugate 1. 


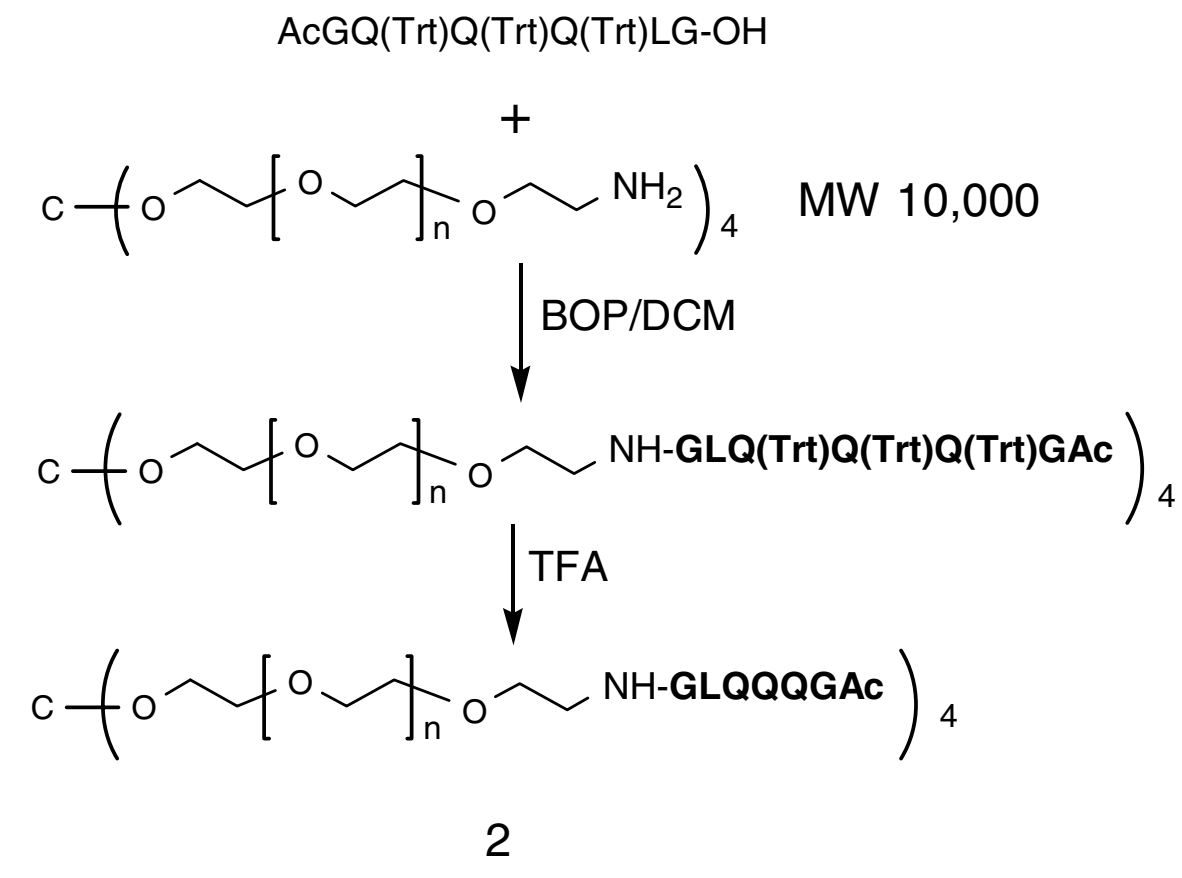

Scheme S2. Synthesis and structure peptide-PEG conjugate 2.

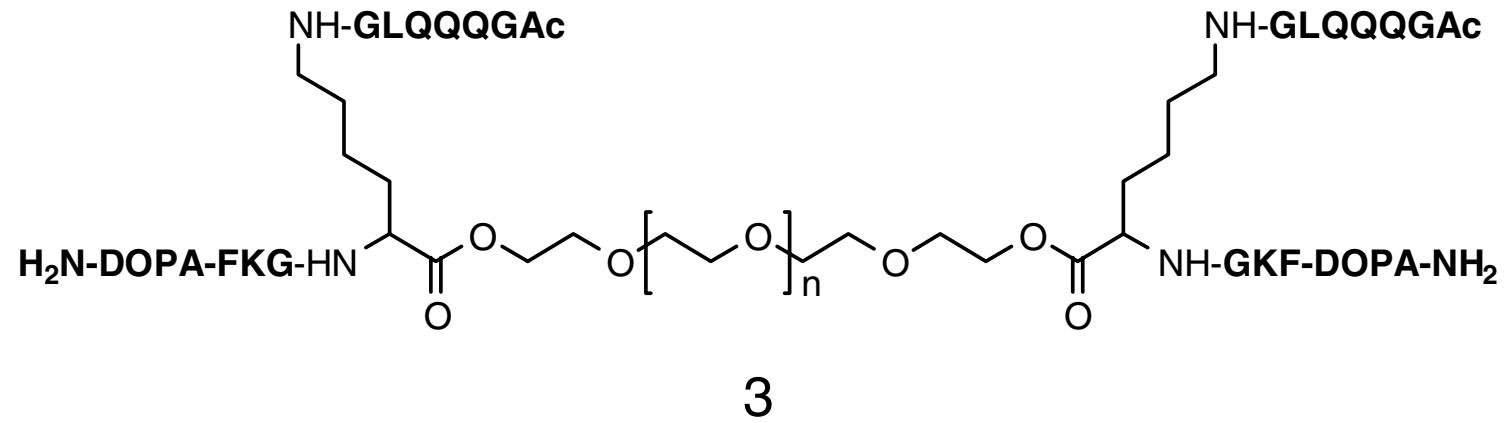

Scheme S3. Structure of peptide-PEG conjugate 3. 


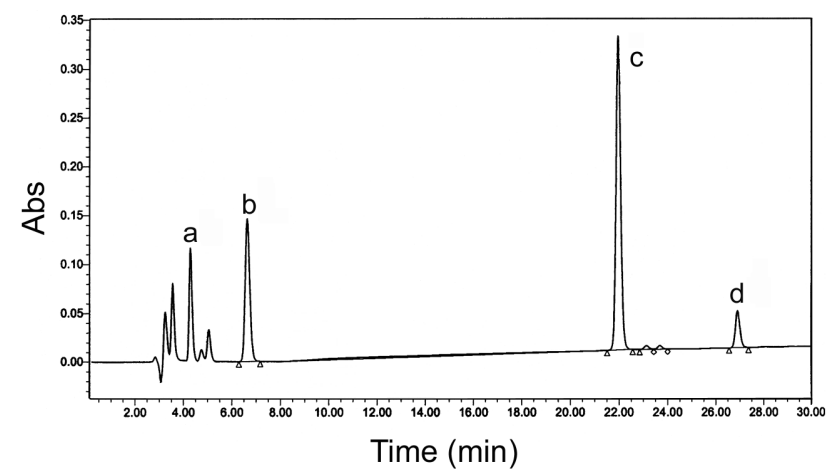

Figure S1. RP-HPLC analysis of the reaction mixture containing Ac-Phe-Lys-Gly- $\mathrm{NH}_{2}(0.1 \mathrm{mM})$, dns- $\varepsilon$-aca-QQIV $(0.5 \mathrm{mM})$, and guinea pig liver transglutaminase $(0.02 \mathrm{U} / \mathrm{ml})$ at $25{ }^{\circ} \mathrm{C}$ after $12 \mathrm{~min}$. The peaks were confirmed by LC-ESI/MS (Fig. 3) as Ac-Phe-Lys-Gly-NH ${ }_{2}$ (a), ${ }^{\varepsilon} \mathrm{N}-$ dansyl-L-lysine (b), dns- $\varepsilon$-aca-QQIV (c), and product (d).
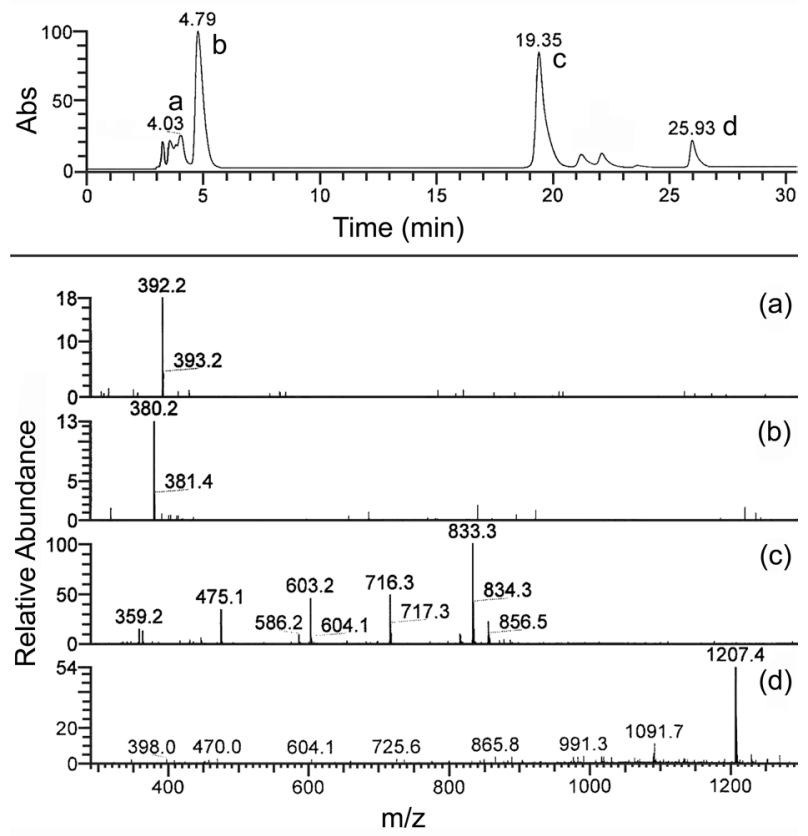

Figure S2. LC-ESI/MS analysis of the reaction mixture containing Ac-Phe-Lys-Gly- $\mathrm{NH}_{2}(2.4 \mathrm{mM})$, dns- $\varepsilon$-aca-QQIV $(0.5 \mathrm{mM})$ and guinea pig liver transglutaminase $(0.02 \mathrm{U} / \mathrm{ml})$ at $25^{\circ} \mathrm{C}$ after $9 \mathrm{~min} . \mathrm{M} / \mathrm{z} 392.2(\mathrm{M}+1)$ : Ac-Phe-Lys-Gly-NH ${ }_{2}^{2}$ (a); m/z 380.2 (M+1): ${ }^{8} \mathrm{~N}-$ dansyl-lysine (b); m/z 833.3 (M+1): dns- $\varepsilon$-aca-QQIV (c); and m/z $1207.4(\mathrm{M}+1)$ : the cross-linking product (d). 


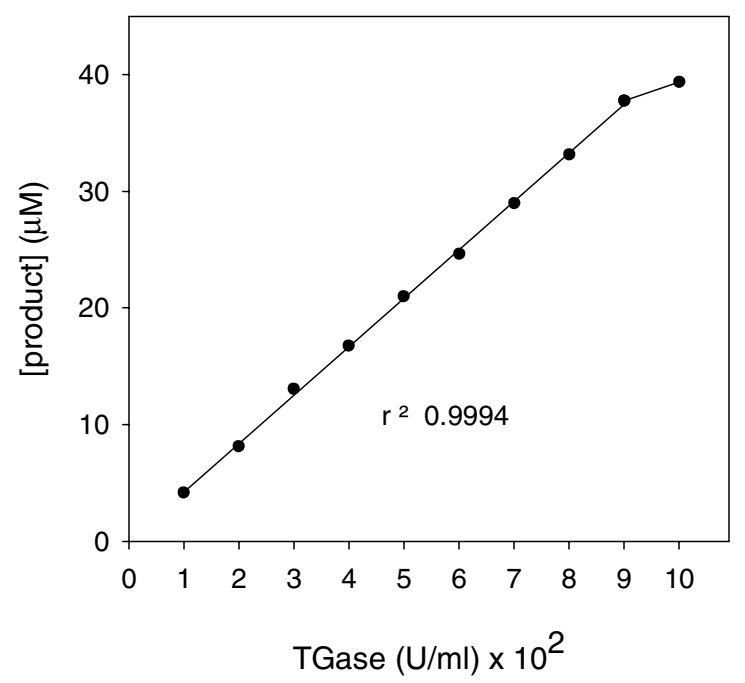

Figure S3. Product formation at $2 \mathrm{~min}$ versus concentration of guinea pig liver transglutaminase for Ac-Phe-Lys-Gly- $\mathrm{NH}_{2}(0.1 \mathrm{mM})$.

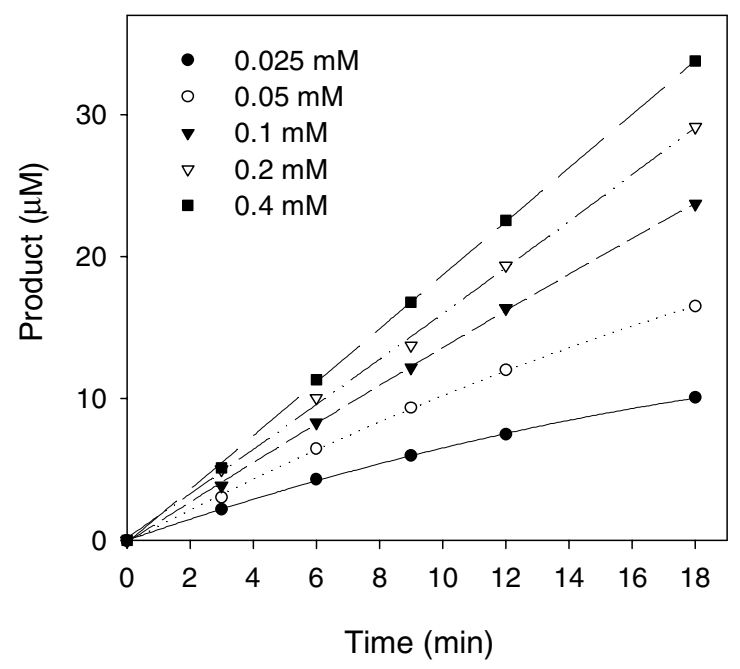

Figure S4. Time course of the reaction between various concentrations of DOPA-Phe-Lys-Gly- $\mathrm{NH}_{2}$ and dns- $\varepsilon$-aca-QQIV $(0.5 \mathrm{mM})$ catalyzed by guinea pig liver transglutaminase $(0.01 \mathrm{U} / \mathrm{ml})$. 


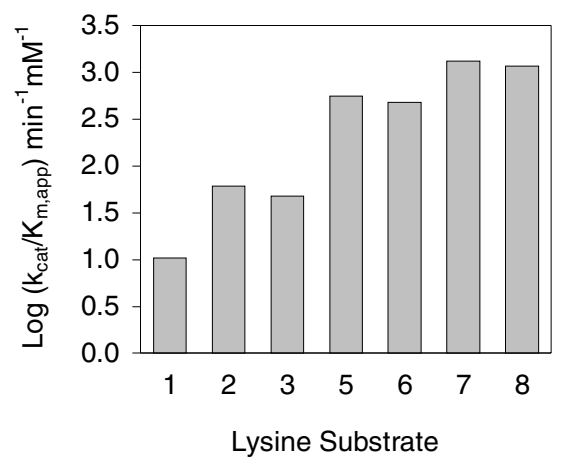

Figure S5. Comparison of the specificity $\left(\mathrm{k}_{\mathrm{cat}} / \mathrm{K}_{\mathrm{m}, \text { app }}\right)$ of liver transglutaminase toward lysine peptide substrates. The $\log \left(\mathrm{k}_{\mathrm{cat}} / \mathrm{K}_{\mathrm{m}, \text { app }}\right)$ values were calculated

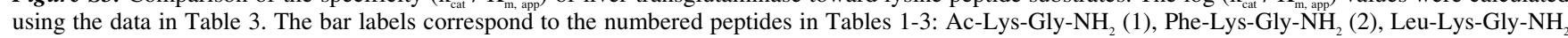
(3), Ac-Phe-Lys-Gly-NH $\mathrm{NH}_{2}$ (5), Ac-Leu-Lys-Gly- $\mathrm{NH}_{2}$ (6), DOPA-Phe-Lys-Gly-NH $\mathrm{NH}_{2}$ (7), and DOPA-Leu-Lys-Gly-NH $\mathrm{N}_{2}$ (8). No cross-linking product was detected with DOPA-Lys-Gly- $\mathrm{NH}_{2}(4)$.
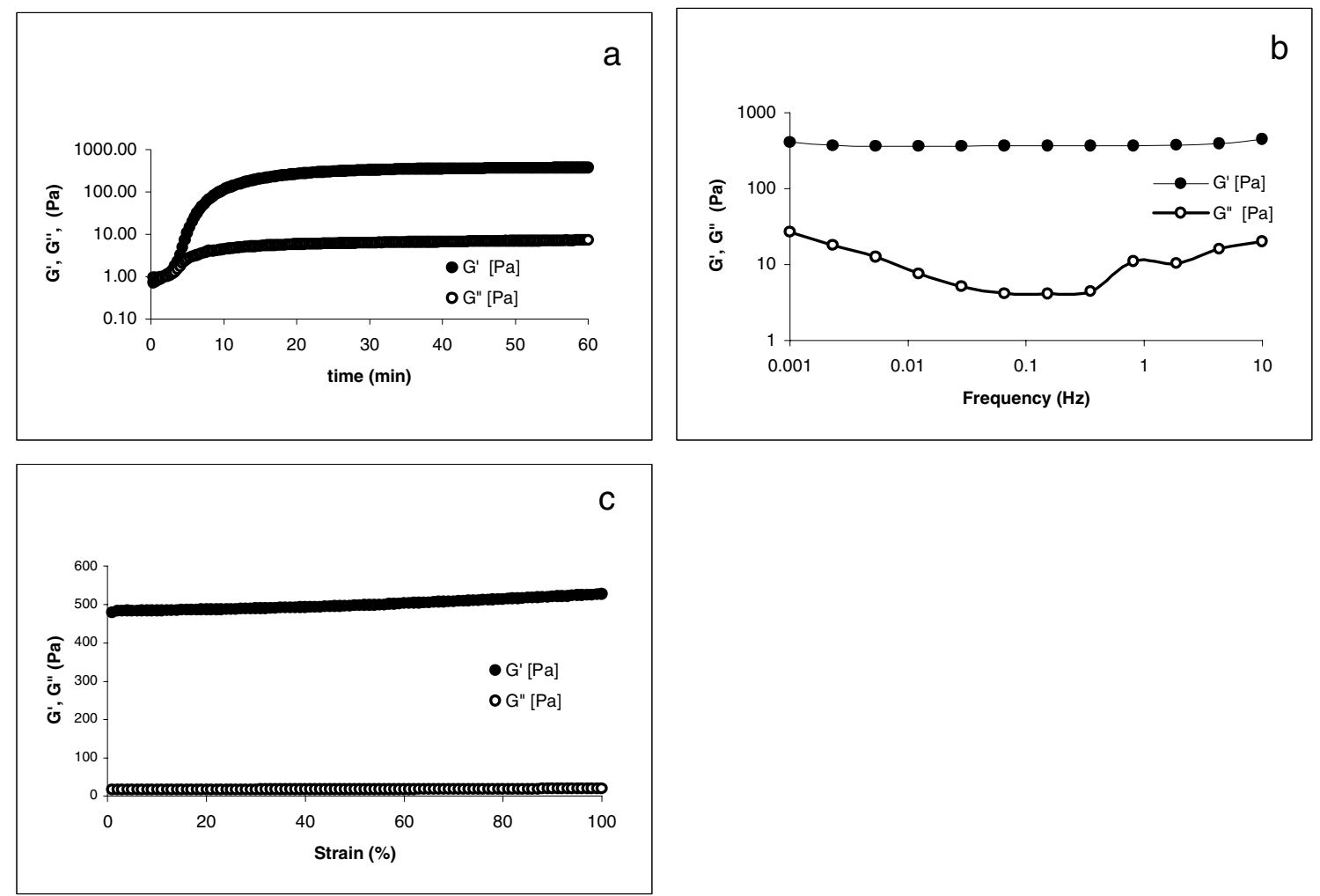

Figure S6. Oscillatory rheology of hydrogel containing $4 \mathrm{mM}$ PEG4aQ and $4 \mathrm{mM}$ PEG4KK in $100 \mathrm{mM}$ MOPS, pH 7.2, $10 \mathrm{mM} \mathrm{CaCl}, 5 \mathrm{mM}$ DTT, $1 \mathrm{mM}$ EDTA, and $4 \mathrm{U} / \mathrm{ml}$ tissue transglutaminase. a. storage modulus versus time during crosslinking; b. frequency sweep at $1 \%$ strain after 60 minutes crosslinking at $37^{\circ} \mathrm{C}$; c. strain sweep at $1 \mathrm{~Hz}$ frequency after frequency sweep experiment. $\mathrm{G}^{\prime}=$ storage modulus; $\mathrm{G}^{\prime \prime}=$ loss modulus. 